\title{
Model Management Activity Community Learning Center (CLC) Based on Local Wisdom to Improve Quality of Nonformal Education Service
}

\author{
Joni Rahmat Pramudia, Sardin, Nike Kamarubiani, Muhammad Irfan Hilmi \\ Department of Non-formal Education \\ Education Sciences Faculty \\ Universitas Pendidikan Indonesia \\ Indonesia \\ jonirp@upi.edu
}

\begin{abstract}
For the majority of the Indonesian people CLC is a relatively new model, which was adopted through a top-down approach, so empirically CLC is growing like mushrooms in the rainy season. Moreover, in the processes was accompanied by incentive funds are relatively large. This study reviews the development of the management model of Community Learning Center (CLC) based on local wisdom in West Java to improve the quality of non-formal education services. Concepts and theories that are used as a reference at the same knife analysis is the study of the Quality Management of Non-formal Education Provider Organization and the concept of Community Learning Center. This study used a qualitative approach to research procedures development (research and development) is commonly abbreviated as $R \& D$. The location of the research been conducted in West Java, Bandung, Cimahi, Bogor, Tasikmalaya, and Karawang. The results showed that CLC management model based on local wisdom contain educational values of cultural and social developed in the community. Local educational values embodied in the culture of society has its own peculiarities that can be developed and preserved through learning activities in CLC.
\end{abstract}

Keywords-Model Development, Management, CLC, Local Wisdom, Non-formal Education Service Quality

\section{INTRODUCTION}

As a subsystem of national education, non-formal penddikan lines are faced with two major challenges of development, ie, first, how the non-formal education is able to carry out a national commitment to improve and develop the quality of education; and secondly, how effective non-formal education can play a role to help resolve the various issues facing the lower layers of society, which has various limitations and powerlessness structurally and culturally as a result of geological and socio-demographic. Approaches to always integrate quality aspects in designing and developing programs for non-formal education and education involving all stakeholders, is a strategy to address these challenges. Because for non-formal education programs that do not take into consideration the quality will not be effectively implemented.

Results of a preliminary study carried out showed that the condition of non-formal education units and management of the programs, is far from the expected quality standards.
Special Community Learning Center (CLC), despite policies that encourage the growth and strengthening of CLC is done on a massive scale, but the quality is still showing the percentage of unsatisfactory. CLC was established as a container to accommodate the aspirations and ideas of practitioners CLC is not yet able to realize synergies program that leads to quality improvement. Thus, the realization of independent CLC, advanced as well as sticking to the principle of useful and efficient for the benefit of society, is also not yet been achieved. Some of the factors supporting the successful development of the program PKBM [2] include: a) the ability to identify and record the needs of the community (the learners), b) serve the needs and interests of learners in varied activities or according to the needs and interests, c) mobilize existing resources in communities, d) build partnerships and cooperation are open to various institutions or organization, so CLC able to develop various activities of community development in accordance with local needs, e) monitor the progress of activities and the success that basis future program development, f) notes the many advantages and the lack of activity in the CLC institution.

The empirical fact is further corroborated by the lack of support policies that expressly and explicitly set the quality standard of non-formal education. In fact, the National Education Act [1] has mandated that between formal education and non-formal education should not be anyone in the step child. But in fact, facilities and infrastructure for non-formal education is far below the average of formal education. Similarly, quality managers and tutors / facilitators / tutors, course of study, culture and interest in learning communities as residents learn that the low, the yeast study, study groups, institutions of learning, and the issue of lack of funds to learn, everything becomes a serious problem interrelated and ultimately have implications also on the low quality of graduates.

Some relevant research of them conducted at Kasetsart University in Thailand that the people participating in the learning process in the form of local wisdom that contains the culture and customs [3]. Related research is described and discussed in Ref. [4] - [7]. 
In relation to the issues and ideas above, is necessary to conduct a comprehensive study on "Management Model Development Community Learning Center-Based Local Wisdom for Improving the Quality of Non-formal Education Service (CLC Management Model Development Studies in West Java)". Region (scope) of research include the study of theoretical conceptual Coomunity Learning Center in West Java, relevanced with empirical studies on the units and the management of the overall educational program.

\section{METHOD}

CLC management model based on local wisdom contain educational values of cultural and social developed in the community. Local educational values embodied in the culture of society has its own peculiarities that can be developed and preserved through learning activities at CLC.

Conceptualization CLC management model was developed based on local wisdom refers to the procedure of research development. The formulation conceptual model referring to the results of the study the management of an exploratory study on the characteristics of local wisdom PKBM institutions, potential institutional, institutional and program characteristics PKBM and standards / quality parameters CLC management. Empirical grounding in the preparation of the conceptual model CLC management refers to the result of in depth study conducted at five institutions that have certain characteristics in this study. The conceptual model that has been validated by an expert / experts / academics and practitioners of non-formal education in West Java. Validation by experts conducted through focus groups (Focus Group Discussion). Once validated by experts and practitioners of non-formal education, this model was later revised that gave birth to the conceptual model CLC management based on local wisdom, which is ready to be implemented and tested its effectiveness in improving the quality of non-formal education services, as presented in Figure 1.

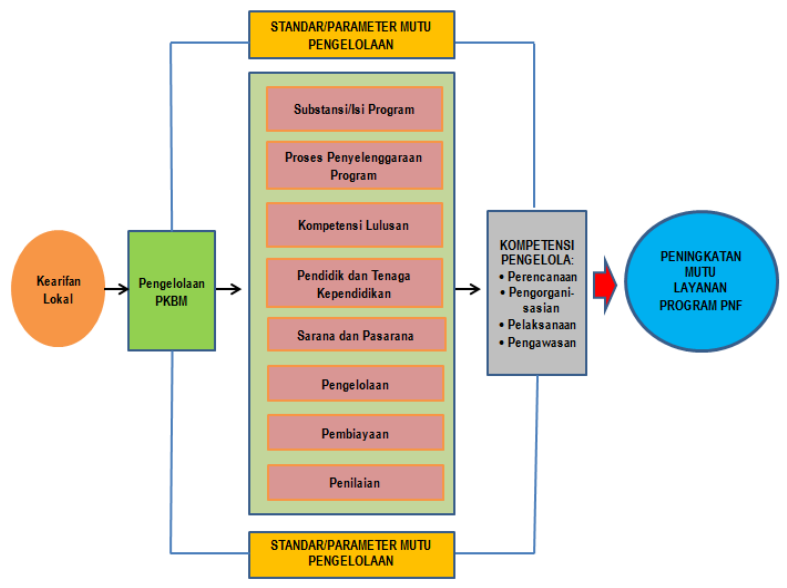

Fig. 1. Conceptual Model CLC Management Based Local Wisdom

\section{A. Characteristics of Local Wisdom Institution Institution CLC}

Distinctiveness or local wisdom in the CLC unit has a diversity that is based on the opportunities and potential of the institution, the region around institutions, natural resource agencies, up to the potential possessed by the learners. In general, CLC institutions that are in this area of research emphasizes the distinctiveness / local knowledge includes the field of art and culture, processed food, and the local language skills and local crafts.

\section{B. The CLC Institutional Potential-Based Local Wisdom}

Potential Community Learning Center institutions that are the hallmark that include human resource managers and resource persons from academic institutions (universities tiunggi public and private), then the resources surrounding environment CLC institutions that developed in the region area CLC institutions. The potential value of local wisdom that was developed and characterized the delivery of the institution of art and culture, skill and processed foodstuffs. Some types of skills are identified and developed in PKBM in utilizing local potential are: courses dressmaking, cookery, hairdressing beauty, hair clippers, acupuncture, cooking, massage and others. The programs were developed to improve the knowledge and skills in order to support the profession (professional). CLC programs developed vary and depend on the interests and needs of target students or residents to learn as an effort to improve community participation in the activities of CLC institutions.

\section{Mapping Characteristics of Institutional and Program- Based Local Wisdom}

Characteristics encountered in general in this area of research among which the development of life skills and the development of reading culture. CLC program generally targets include early childhood (5-6 years), school age, adolescents, adults and elderly. Based on economic categories, the average implementation CLC program intended for low-income people or not have a job, even though basically CLC program is intended for all people and groups. Learning activities conducted by the CLC held involving various parties, especially partners, both public and private as well as public as the main target in a participatory manner. In general the program of activities organized in PKBM performed in groups because it facilitates the monitoring and evaluation activities, and there are times when the implementation guidelines for the specific program should be done in groups.

\section{Standards / Quality Management Parameters CLC Based Local Wisdom}

In general, CLC institutions own acauan competency standards or reference standards are adequate. This follows the implementation of the technical instructions from the government program. Standard content will be poured into the curriculum documented on the education calendar as a reference in the implementation of a program. In the standard process, in general, CLC institutions own the completeness of the curriculum and adequate administration of which complete syllabus or lesson plans semesters and SAP. Standard teachers and education personnel in institutions in general CLC own qualification of S1 and D IV. CLC institutions largely supported by individual ownership of infrastructure, both home and built a special place for CLC. This is because the birth of 
the CLC for the initiation of individuals / groups, although some CLC occupy public facilities such as meeting building RW, village, schools, and other buildings.

Management of the Institute as a whole has led CLC by a graduate (S1) although not all scholars in the field of education. While the non-formal education have been followed by the leader among which the CLC CLC management training institutions and strengthening of institutions PNFI. Overall the administrative requirements CLC own institution vision statement, mission, objectives and annual plans, schedule of activities are arranged, the results of monitoring and evaluation of the programs organized by the CLC, the report documents the results of the implementation of the program both on the programs and finances.

In the aspect of financing, the funds available in the CLC sourced from non-governmental organizations and aid from the fund blockgrant program subsidized by the government. Generally all CLC appraiser has determined criteria such as what will be done to the program organized. The type of assessment that is often used in institutions such CLC written test and practice.

Further conceptual model that has been built, and tested and tested in order to test the effectiveness of this model is presented in the following description.

- There are significant differences in the competence of managers using CLC management based on local wisdom to those not using CLC management based on local wisdom.

- There are significant differences in the quality of services PNF program that uses CLC management based on local wisdom to those not using CLC management based on local wisdom.

Effectiveness test conducted in a manner by comparing the average post-test score gap in the experimental group and control group. Form of treatment of the experimental group is in the form of application management model based on local wisdom CLC conducted over three months, consisting of the preparation of one month, one month month implementation, and evaluation and follow-up for one month.

Previous normality test to determine the distribution of each variable. The results of the test for normality using Komogorof-Smirnov test with the results shown in table 1.

TABLE I. ONE-SAMPLE KOLMOGOROV-SMIRNOV TEST

\begin{tabular}{|c|c|c|c|c|c|}
\hline & & $\begin{array}{c}\text { KompetensiPe } \\
\text { ngelolaBdg }\end{array}$ & $\begin{array}{c}\text { MutuLayana } \\
\text { nPNFBdg }\end{array}$ & $\begin{array}{l}\text { KompetensiPe } \\
\text { ngelolaBgrTsk }\end{array}$ & $\begin{array}{c}\text { MutuLayan } \\
\text { anPNFBgrT } \\
\text { sk }\end{array}$ \\
\hline $\mathrm{N}$ & & 40 & 40 & 40 & 40 \\
\hline \multirow{3}{*}{$\begin{array}{c}\text { Normal } \\
\text { Parameters }\end{array}$} & Mean & 28,78 & 216,83 & 30,66 & 205,93 \\
\hline & Std. Deviation & 3,743 & 21,834 & 4,027 & 19,199 \\
\hline & Absolute & 148 & ,083 & 127 & 136 \\
\hline \multirow{2}{*}{$\begin{array}{l}\text { Most Extreme } \\
\text { Differences }\end{array}$} & Positive & ,148 & ,083 &, 127 & , 136 \\
\hline & Negative &,- 094 &,- 071 &,- 104 &,- 088 \\
\hline \multicolumn{2}{|c|}{ Kolmogorov-Smirnov Z } & ,934 &, 527 & 801 & ,858 \\
\hline \multicolumn{2}{|c|}{ Asymp. Sig. (2-tailed) } & ,347 & 944 & ,542 & ,453 \\
\hline
\end{tabular}

b. Calculated from data.
Based on the results of the above normality test result that all the variables in this study with normal distribution, because the significance value greater than 0.05 .

Comparison test results in this study was formulated as follows: "there are significant differences in competence and quality of services that use the program PNFI CLC management model based on local wisdom and not".

Schematically, the model correlational relationship expressed in the hypothesis can be described as follows.

- Identification of a significant difference in the competence of trainees using CLC management based on local wisdom to those not using CLC management based on local wisdom,

- Identification of significant differences in the quality of services PNF program that uses CLC management based on local wisdom to those not using CLC management based on local wisdom.

Test depending on the competence of trainees using CLC management based on local wisdom to those not using CLC management based on local wisdom seen in table 2 .

TABLE II. PAIRED SAMPles STATISTICS SUB HyPOTHESIS 2.1

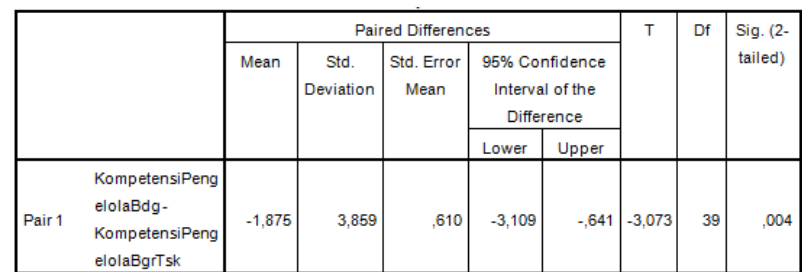

Analysis of the results of calculations of Table 2. Paired Samples test illustrates the results of paired $t$ test. Significance value of $0.004(\mathrm{p}<0.05)$, then reject Ho, meaning that there is a difference competency training significantly between groups that implement CLC management model based on local wisdom by not implementing the model. Rated $95 \%$ confidence interval is between -3.109 to -0.641 .

If the competence of trainees using CLC management model based on local wisdom by not implementing CLC management model based on local wisdom are the same, then the chances of factors that explain it is $0.004 \%$ to obtain a mean difference of -1.875 . Because the opportunity to explain the results of less than $5 \%$, then the result is meaningful.

$95 \%$ degree of confidence that if the measurement is made at the population level, the difference in value between the competence of CLC management model based on local wisdom with which neither is between -3.109 to -0.641 .

Then, different test on a Quality of Service Program PNF trainees using CLC management model based on local wisdom to those not using CLC management model based on local wisdom is presented in Table 3. 
TABlE III. Paired SAmples Statistics Sub Hypothesis 2.2

\begin{tabular}{|c|c|c|c|c|c|c|c|c|c|}
\hline & \multicolumn{5}{|c|}{ Paired Differences } & \multirow[t]{3}{*}{$\mathrm{t}$} & \multirow{3}{*}{ df } & \multirow{3}{*}{$\begin{array}{l}\text { Sig. (2- } \\
\text { tailed) }\end{array}$} \\
\hline & & \multirow[t]{2}{*}{ Mean } & \multirow[t]{2}{*}{\begin{tabular}{|c|} 
Std. \\
Deviatio \\
$\mathrm{n}$
\end{tabular}} & \multirow[t]{2}{*}{$\begin{array}{l}\text { Std. Error } \\
\text { Mean }\end{array}$} & \multicolumn{2}{|c|}{$\begin{array}{l}95 \% \text { Confidence } \\
\text { Interval of the } \\
\text { Difference }\end{array}$} & & & \\
\hline & & & & & Lower & Upper & & & \\
\hline Pair 1 & $\begin{array}{l}\text { MutuLayanan } \\
\text { PNFBddg- } \\
\text { MutuLayanan } \\
\text { PNFBgrTsk } \\
\end{array}$ & 10,893 & 27,025 & 4,273 & 2,250 & 19,536 & 2,549 & 39 & 015 \\
\hline
\end{tabular}

Table 3 illustrates the results of paired t test. Significance value of 0.015 ( $\mathrm{p}<0.05)$, then reject Ho, meaning that there are differences in the independence of the course participants significantly between the study groups are applying the learning model independent by not implementing the model. Rated $95 \%$ confidence interval is between 2.250 to 19.536 .

If the independence of the course participants with the use of independent learning by not implementing self-learning methods are the same, then the chances of factors that explain it is $0.015 \%$ to obtain a mean difference of 10.893 . Because the opportunity to explain the results of less than $5 \%$, then the result is meaningful.

95\% degree of confidence that if the measurement is made at the population level, the difference in value-based CLC management trainee with a local wisdom that is not between 2.250 to 19.536 .

\section{CONCLUSION}

CLC management model was developed based on local wisdom refers to the standard / quality parameters, are likely to contain educational values of cultural and social developed in the community. Local educational values embodied in the culture of society has its own peculiarities that can be developed and conserved through management at CLC. The standard approach / management quality parameters applied in the context of the management of CLC, was held involving various components or elements of CLC institutions, including the people in the neighborhood CLC.

\section{ACKNOWLEDGMENT}

The author would like to thank the Directorate of Higher Education, Ministry of Research, Technology and Higher Education, Indonesia who have funded this research activity.

\section{REFERENCES}

[1] Sihombing dan Gutama (2000). PKBM dalam Perspektif Pendidikan Luar Sekolah. Jakarta: Depdiknas.

[2] Undang-Undang RI Nomor 20 Tahun 2003, tentang Sistem Pendidikan Nasional.

[3] Sompong, N and Nataphon R. (2015). "The development model of knowledge management to strengthenThai ICT community learning center". Procedia - Social and Behavioral Sciences 176, hal. $139-147$

[4] Jonas, A. I and Vanclay F., (2016). "Experiencing local community resilience in action: Learning from post-disaster communities". Journal of Rural Studies 47, hal. 204-219

[5] M. Wendelin K and Pauleen D. (2015). "Learning wisdom: Embodied and artful approaches to management education". Scandinavian Journal of Management 31, hal. 493-500.

[6] Gökçearslan S and Alper A.(2015). The effect of locus of control on learners' sense of community and academic success in the context of online learning communities. Internet and Higher Education 27 hal. 6473.

[7] Yilmaz R. (2016). Knowledge sharing behaviors in e-learning community: Exploring the role of academic self-efficacy and sense of community. Computers in Human Behavior 63, hal. 373-382. 